\title{
Biometric studies on premetamorphic eel larvae of Anguilla anguilla (Anguilliformes: Anguillidae) in comparison with younger developmental stages of the species
}

\author{
B. Strehlow \\ Universität Rostock, Fachbereich Biologie, Zoologisches Institut; Universitätsplatz 2, \\ D-18055 Rostock, Germany
}

\begin{abstract}
Anguillidae caught off the west coast of Europe were examined taxonomically and compared with the youngest developmental stages of larvae of Anguilla anguilla caught in the Sargasso Sea 1979 (Schoth, 1982). The total number of myomeres and the number of myomeres up to the third, opistonephritic blood vessel present features of this species which are significantly different from those of the larvae of Anguilla rostrata and do not change during the whole larval phase. A combination of these two biometric features enables an infallible species identification of the Atlantic Anguilla larvae at all developmental stages. The number of predorsal and preanal myomeres, the preanal length and features of the head cannot be used for a distinction of Anguilla larvae. One larva, $68.7 \mathrm{~mm}$ long, with 107 myomeres, and 44 myomeres to the opistonephritic blood vessel represents the hitherto southernmost record of an A. rostrata larva in the eastern North Atlantic.
\end{abstract}

\section{INTRODUCTION}

Leptocephali of Anguilla anguilla are among the most common eel larvae in the North Atlantic. Schmidt (1909) classified the eel larvae of the species into three age groups: 0-group ( $7-37 \mathrm{~mm})$, I-group $(40-70 \mathrm{~mm}$ ) and II-group (60-88 mm). According to this classification, the leptocephali caught near the European continental shelf are IIgroup larvae of A. anguilla, which is in accordance with the classification of Castle (1984) who rated the eurydontic stage as premetamorphic. Bast \& Strehlow (1990) have published results on the length composition and abundance of 376 II-group larvae of A. anguilla from the Iberian Basin (northeastern Atlantic). This material is used for a taxonomical examination and a comparison with larvae studied by Schoth (1982) who examined 6710 -group larvae of $A$. anguilla from the Sargasso Sea taxonomically. A comparison of the morphometric and meristic features of different development stages of A. anguilla leptocephali forms the basis for an analysis of the modification of body proportions and taxonomically relevant meristic features in relation to increasing total length and age of the larvae. 


\section{MATERIAL AND METHODS}

During two international expeditions of the Polish R.V. "Prof. Siedlecki" (MIR, Gdynia) from 16 July to 12 October 1984 in the Iberian Basin and from 31 March to 18 April 1985 in the region of the Middle Atlantic Bridge, north of the Azores, more than 500 leptocephali and a great number of adult anguilliform fishes of several species were caught. It should be mentioned that the expeditions were performed to investigate the valuable epi- and mesopelagic fishery resources; the program and the equipment of the cruises were not designed especially for investigations of eel larvae. In 1984, a modified krill trawl with a mesh size of $4.5 \mathrm{~mm}$ and an opening of $15.7 \mathrm{~m}^{2}$ was usedi in 1985 a pelagic trawl net with an inlet mesh size of $6 \mathrm{~mm}$. The depths of the hauls were measured by an echo sounder, but conclusions on the vertical distribution of the collected larvae must be treated with caution because both gears lacked an opening-closing device. The towing speed was between 2 and $2.5 \mathrm{kn}$.

Leptocephali of the genus Anguilla were captured at 55 out of 109 stations in 1984 and at 6 out of 28 stations in 1985 (for a complete list, see Bast \& Klinkhardt, 1987 and Strehlow, 1988). The larvae of Anguilla species completely lack pigments in the body tissues (Smith, 1979, 1989), and could be easily distinguished from other anguilliform leptocephali. Species identification took place by counting myomeres. 387 leptocephali of the family Anguillidae off the west coast of Europe were examined.

After capture the larvae were fixed on board in $4 \%$ seawater-formalin. Measurements were carried out up to the nearest $0.1 \mathrm{~mm}$ with the aid of an ocular micrometer of a dissecting microscope, investigations for meristic characters with the aid of a microscope with magnifying powers of 100 and 250.

After examination the larval material was stored in the collection of the "Museum für Naturkunde" at the Humboldt University, Berlin (ZMB).

\section{RESULTS AND DISCUSSION}

\section{Total number of myomeres (TNM)}

The TNM presents a typical and genetically fixed characteristic that plays an important role in the identification of species of Anguillidae larvae. The TNM was counted in 375 specimens. 374 were distinguished as Anguilla anguilla leptocephali with 111-119 myomeres $(\varnothing=115.82$; s.d. $=1.54$; cf. Table 1, Fig. 1 ) (Corrigendum in Bast \& Strehlow, 1990: Unfortunately the TNM was published by mistake as $\varnothing=114.82$.). One larva of the treated material was distinguished as $A$. rostrata because of the low value of TNM and MO.

Most of the known data on the total number of myomeres and vertebrae (TNV) of A. anguilla present a possible range of 111 to 120 (Schmidt, 1913; Ege, 1939; Vladykov \& March, 1974; Kleckner \& McCleave, 1980; Kracht, 1982). The mean TNM counted in larger collections of larvae lies between 113 and 116 (Table 1). The mean value of the leptocephali examined during the 1984 and 1985 cruises in the Northeastern Atlantic is therefore near the upper limit of the known values. For reasons concerning the methodology, differences of \pm 1 myomere are normal. Especially the last two myomeres in the tip of the tail are difficult to interpret. In fact, it cannot be excluded that an almost indistinct 
Biometric studies on premetamorphic eel larvae

\begin{tabular}{|c|c|c|c|c|c|c|}
\hline 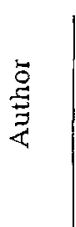 & 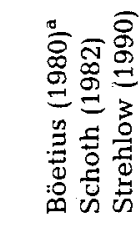 & 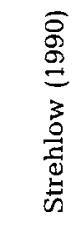 & 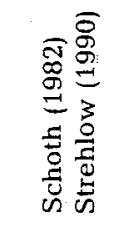 & 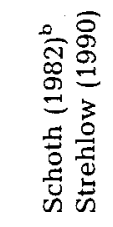 & 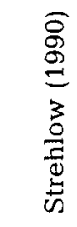 & 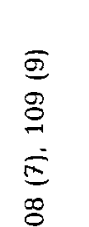 \\
\hline$\ddot{i}$ & 됴욤 & \& & $8 \%$ & 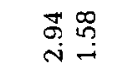 & 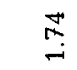 & $\dot{0}$ \\
\hline$Q$ & 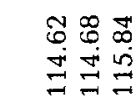 & $\underset{\substack{2 \\
\infty \\
\infty}}{\rightarrow}$ & 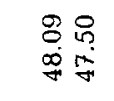 & 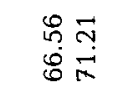 & $\begin{array}{l}8 \\
0 \\
0\end{array}$ & $\begin{array}{l}\frac{5}{o} \\
\dot{0}\end{array}$ \\
\hline చี & 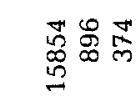 & $\stackrel{\circ}{\circ}$ & 吾煦 & 䎡品 & $\overline{8}$ & $\begin{array}{l}\mathscr{E} \\
\Xi \\
\Xi\end{array}$ \\
\hline & & & & $\sin$ & & $\stackrel{2}{0}$ \\
\hline & & & & 䓋の & & $\dot{\Xi}$ \\
\hline & & & & $m \infty$ & & $\stackrel{.}{\varrho}$ \\
\hline & & & & $\mathbb{N} \sigma \underset{\infty}{m}$ & & 胥 \\
\hline & & & & 모용 & & $\underbrace{}_{\infty}$ \\
\hline & $\stackrel{\nexists}{\leftrightarrows} 1-1$ & & & 용 & & 3 \\
\hline & 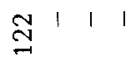 & & & gi & & 壳京 \\
\hline & $\Xi 1-1$ & & & $\because$ 우 $\sigma$ & & $\begin{array}{l}\overline{0} \Sigma \\
\sum_{0} \\
0\end{array}$ \\
\hline$\stackrel{5}{9}$ & 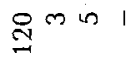 & & & 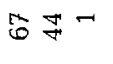 & & $\begin{array}{ll}2 \\
0\end{array}$ \\
\hline$\vec{\Xi}$ & $\stackrel{g}{=} \underset{\sim}{ }$ & & & $\mathscr{B} \underset{7}{ } 1$ & & $\begin{array}{l}3 . \Xi \\
y .0 \\
0.9\end{array}$ \\
\hline $\begin{array}{l}7 \\
\vdots \\
z\end{array}$ & $\stackrel{\infty}{=} \overrightarrow{\vec{N}} \vec{\forall} \vec{\nabla}$ & & & 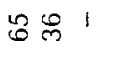 & & 记 \\
\hline$\underset{\Phi}{\stackrel{G}{G}}$ & 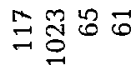 & & & & 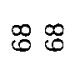 & 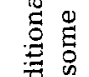 \\
\hline 㞱 & 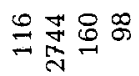 & N - & $\vec{n}^{\infty} 1$ & $8 \underset{9}{9} 1$ & $\tilde{6}$ & $\begin{array}{l}\pi \\
0 \\
0\end{array}$ \\
\hline & 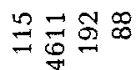 & $\vec{N}$ & $\sin ^{\circ}$ & $\mathscr{\delta} \pm 1$ & 88 & $\begin{array}{l}\overrightarrow{2} \\
\vec{\sigma} \\
=\end{array}$ \\
\hline & 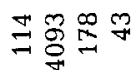 & 尺 : & $g \underset{\forall}{g}$ & $\overrightarrow{0} \forall 1$ & 88 & 节 \\
\hline & 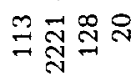 & क्ष & 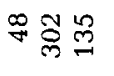 & $8^{n} 1$ & ठ̈ & 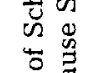 \\
\hline & 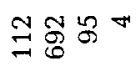 & $\stackrel{\infty}{\rightarrow}$ & 疋尔 & in $N 1$ & 3 & $\stackrel{n}{3}$ \\
\hline & 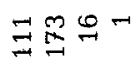 & $=\overline{5}$ & 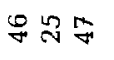 & $\begin{array}{lll}\infty & 1 & 1\end{array}$ & $\tilde{0} \stackrel{0}{-1}$ & 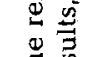 \\
\hline & 옳 & $\mathscr{c}^{m}$ & $\operatorname{q} \% \sim N$ & $i^{n}-1$ & $6^{m}$ & 焉焉 \\
\hline 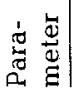 & $\sum_{i=1}^{\sum}$ & $\vec{\Sigma}=$ & $\sum_{\Sigma}=$ & 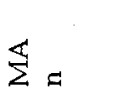 & $\stackrel{\rho}{\Sigma}$ & 总 \\
\hline
\end{tabular}



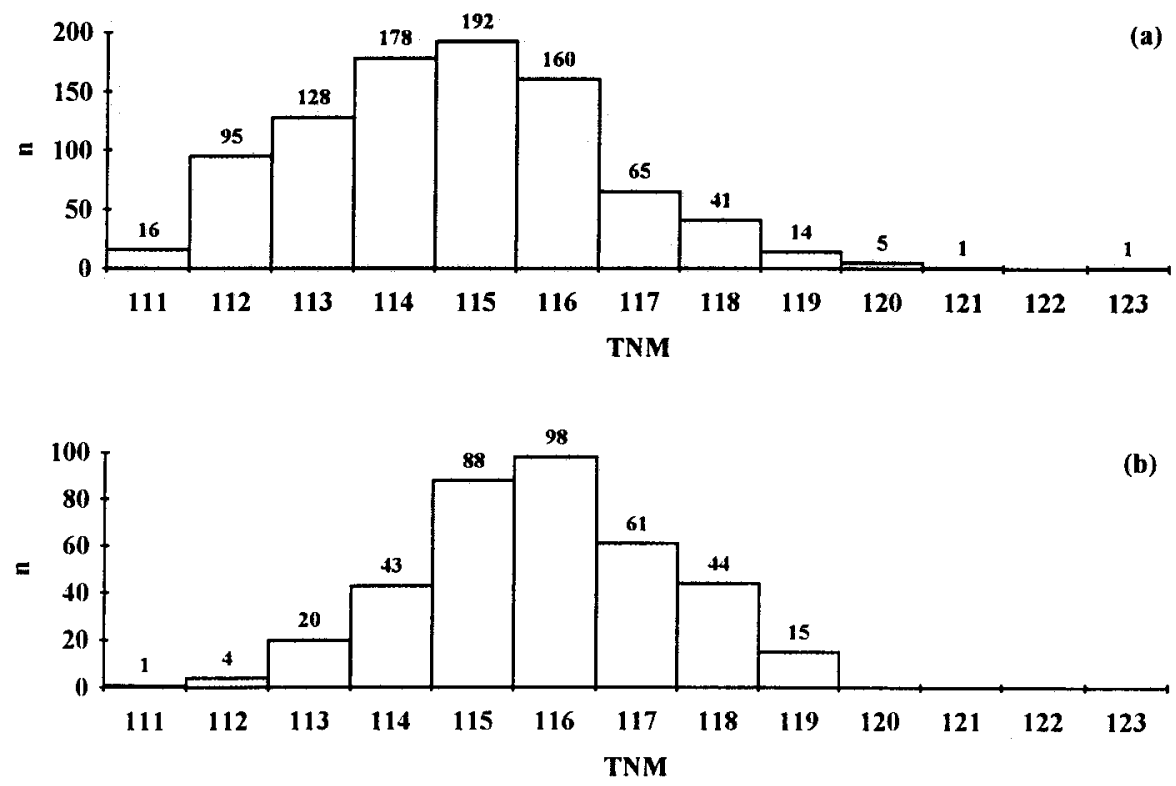

Fig. 1. Frequency distribution of total numbers of myomeres (TNM) for leptocephali of Anguilla anguilla of O-group (a) and premetamorphic stage (b)

differentiation of the last tiny myomeres in the filigree tip of the larval tail does take place. Similar features were found during examinations of Nemichthys scolopaceus larvae (Karmovskaya, 1990; Strehlow, 1990). A possible insignificantly higher TNM with increasing total length of $A$. anguilla larvae is incompatible with the mean values for TNV of European eels $(\varnothing=114.62)$ presented by Böetius (1980). The calculation of, especially, the last two or three myomeres of the tail seems to depend on the subjective methods of the investigators.

However, the similar TNM of $A$. anguilla larvae of the youngest development stages (Schoth, 1982) and of the larvae caught off the west coast of Europe revealed that the total number of myomeres presents a characteristic which does not change during the whole larval phase and can be used for species identification of all life stages without any methodological difficulties. The rare specimens with $111 \mathrm{TNM} / \mathrm{TNV}$ are an exception to this rule. Leptocephali of $A$. rostrata have, on average, 6-8 myomeres less than the A. anguilla leptocephali (Ege, 1939; Vladykov \& March, 1974; Kleckner \& McCleave, 1980; Schoth, 1982). The double peak frequency distribution of the TNM for both Atlantic Anguilla species found by Schoth even for very small specimens that were only a few days old and were caught in the same hauls presents an important argument for a spatial and temporal overlapping of the spawning events of $A$. anguilla and $A$. rostrata in the Sargasso Sea. But the mean difference of 6-8 myomeres is so high that it does provide a practical and sure method to identify leptocephali of $A$. anguilla and A. rostrata. 
Number of myomeres up to the opistonephritic (MO) and pronephritic (MP) blood vessel

To calculate the MO, 380 Anguilla leptocephali were examined. Jespersen (1942) found that the position of blood vessels "is determined according to the myomere which lies off the upper end of the blood vessel where it joins the aorta". In 379 analysed larvae the blood vessel was situated between the 45 th and 50 th myomere $(\varnothing=47.50$; s.d. $=$ 0.93; cf. Table 1, Fig. 2) and therefore the MO is, on average, about two myomeres less than the known value for A. rostrata leptocephali (Schoth, 1982; Wippelhauser et al., 1985). According to Schoth, in about $95 \%$ of the small $A$. anguilla leptocephali the third, opistonephritic blood vessel is situated beyond the 46 th myomere; in $87 \%$ of the larger leptocephali examined in this investigation, it is situated in the same position. The position of this blood vessel therefore seems to be constant in the larval phase of A. anguilla, and the difference between the both Anguilla species in the MO is highly significant and can support the traditional species identification by TNM. In fact, a reliable identification of Atlantic Anguilla larvae is possible by using a combination of TNM and MO.

The MP could be counted in 380 specimens and varies between 16 and $22(\varnothing=$ 18.26; s.d. $=0.90$; cf. Table 1, Fig. 2). There are no comparable data from other
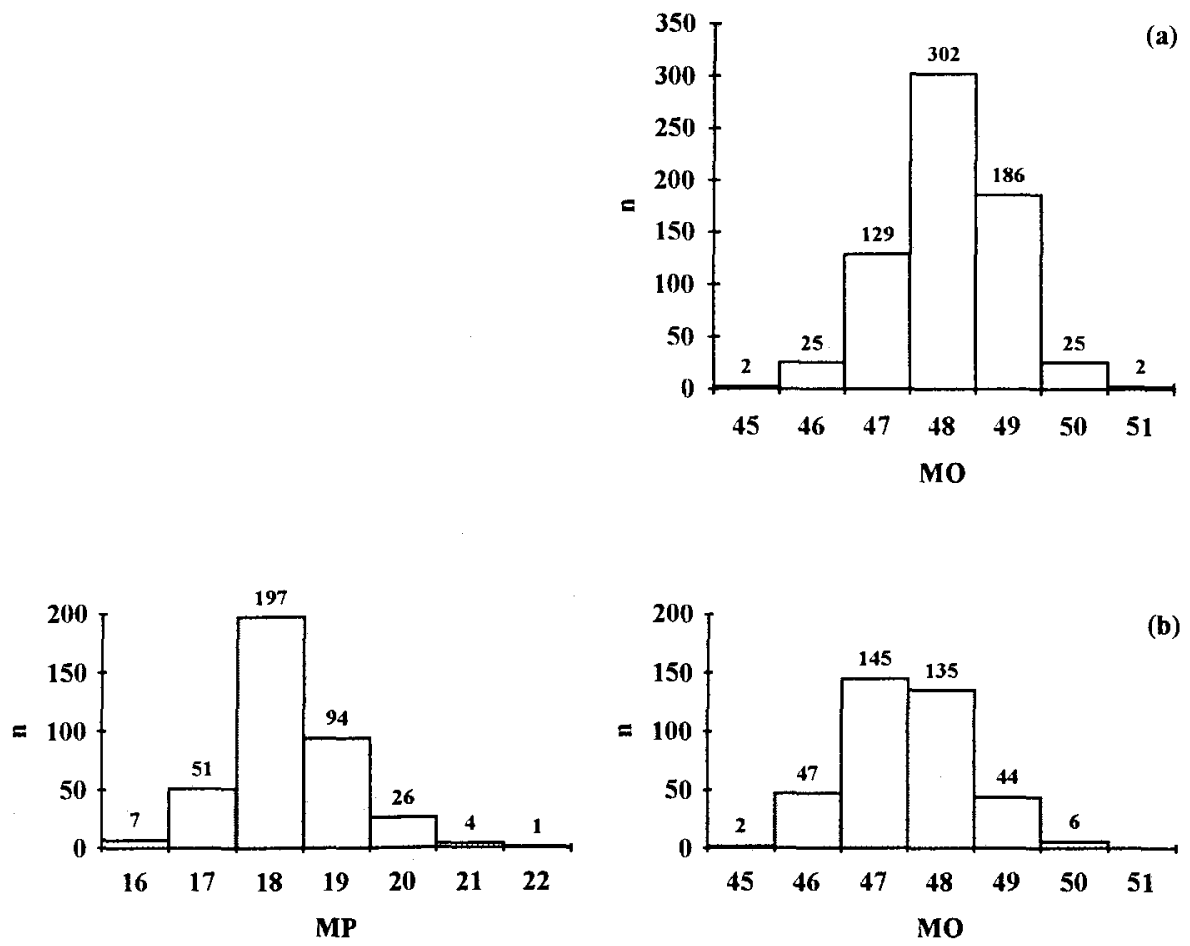

Fig. 2. Frequency distribution of the number of myomeres to the pronephritic (MP) and opistonephritic (MO) blood vessel for leptocephali of Anguilla anguilla of O-group (a) and premetamorphic stage (b) 
A. anguilla collections. Figure 3 shows that the myomeres up to the several blood vessels are positively correlated with the TNM. The ascent of the regression lines is higher for the characteristics which are more caudally situated.

Schoth (1982) found, for the younger larvae, a different ascent of the regression lines of MO compared with those for the larger larvae analysed in this study. This has methodological reasons. In the present case, all individual values of MO were comprised in the regression. Schoth regressed the mean values of MO in TNM-groups (Fig. 3), and the regression line is nearly parallel to the comparable line of our data using the same method. The distance of about one myomere between the parallel lines might be attributed to the subjective methods of counting myomeres. But in that kind of regression all the mean values of MO in the TNM-groups are of the same importance including the means of the very low and very high TNM-groups which only represent a few specimens. For this reason, a regression of all individual MO values depending on the TNM of the same specimens produces clearer results.
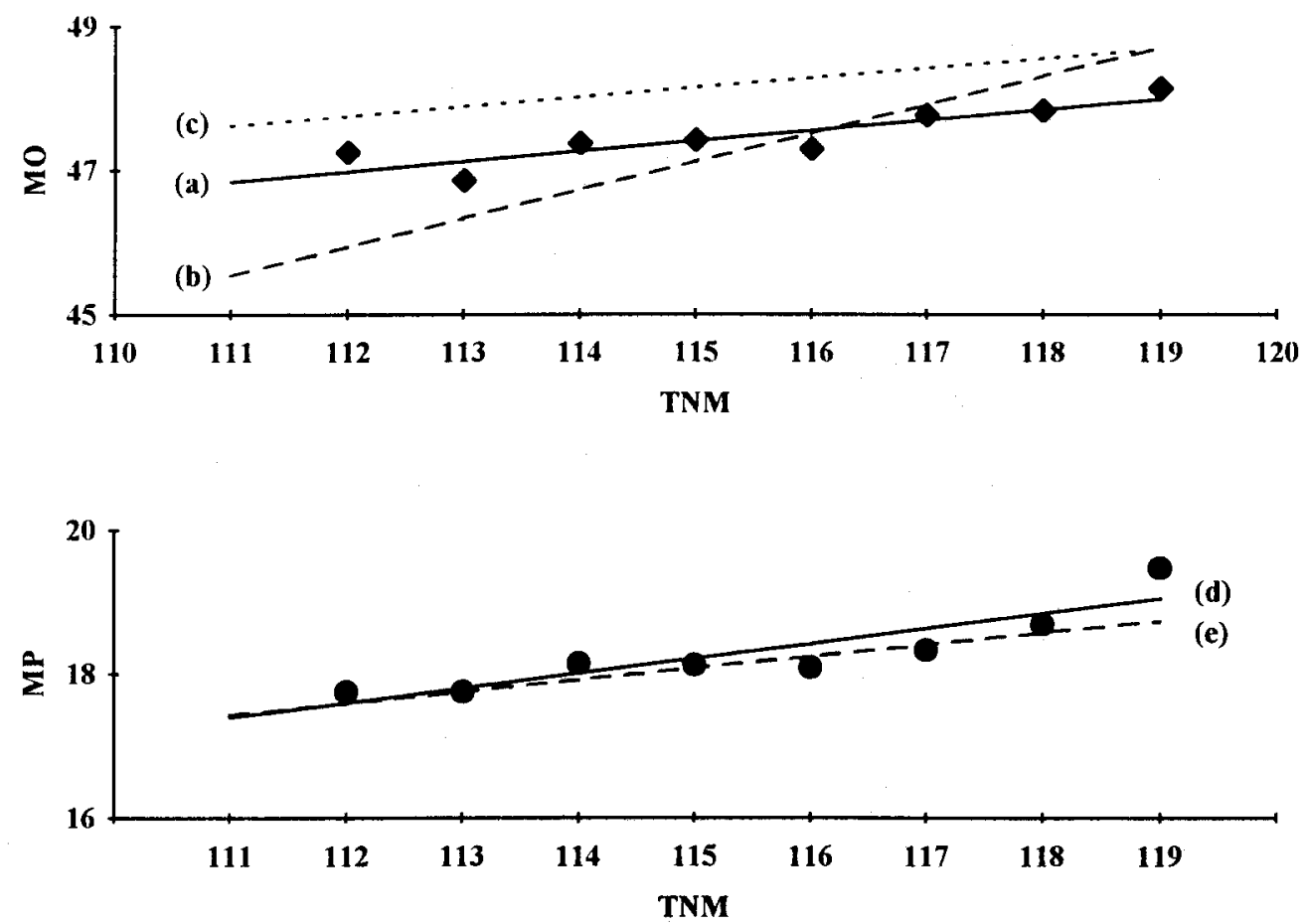

Fig. 3. Regression lines for the position of the pronephritic (MP) and opistonephritic (MO) blood vessel according to the total number of myomeres (TNM) for leptocephali of Anguilla anguilla of O-group (c) and premetamorphic stage $(a, b, d, e)$

(a) $\mathrm{MO}=0.143 \mathrm{TNM}+30.960$ (regression of mean values of $\mathrm{MO}$ in TNM-groups,

(b) $\mathrm{MO}=0.394 \mathrm{TNM}+1.808$ (regression of all individual values of $\mathrm{MO}$ )

(c) $\mathrm{MO}=0.132 \mathrm{TNM}+32.969$ (regression as calculated by Schoth, 1982)

(d) $\mathrm{MP}=0.205 \mathrm{TNM}-5.360$ (regression of mean values of MP in TNM-groups, $\bullet$ )

(e) $\mathrm{MP}=0.162 \mathrm{TNM}-0.549$ (regression of all individual values of MP) 


\section{Number of predorsal myomeres (MD)}

In 371 Anguilla larvae the MD amounted to between 61 and $68(\varnothing=65.67$; s.d. $=$ 1.74 ; cf. Table 1, Fig. 4). The insertion of the dorsal fin of the large A. anguilla larvae collected near Europe lies about 6-7 myomeres before the insertion of the anal fin. Blache (1977) described a typical inter-species decrease of the relative predorsal length of numerous species of eel larvae during their larval phase. It can therefore be expected that

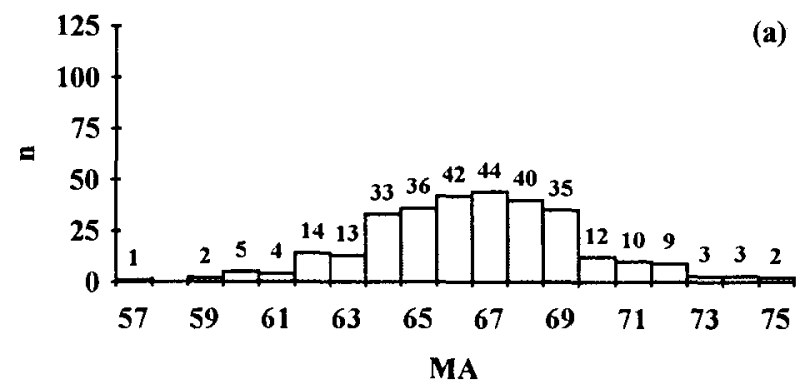

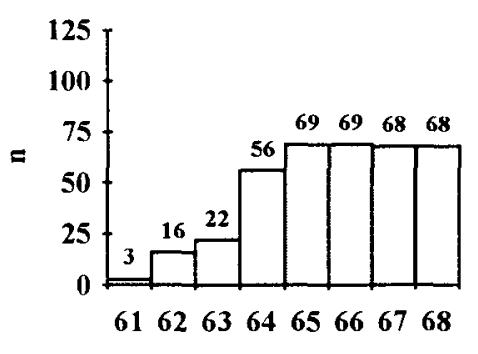

MD

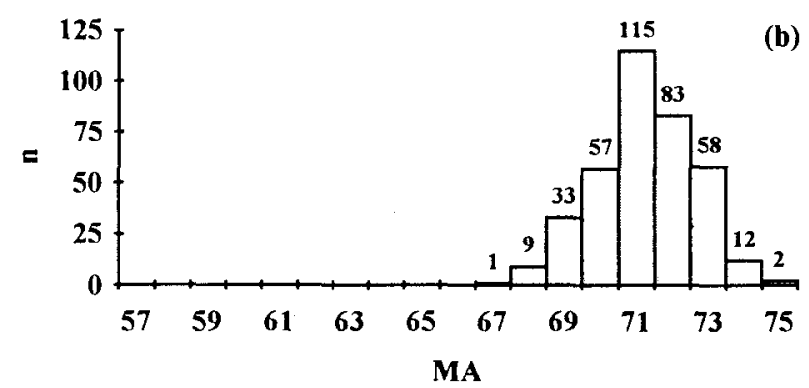

Fig. 4. Frequency distribution of the number of predorsal (MD) and preanal (MA) myomeres for leptocephali of Anguilla anguilla of O-group (a) and premetamorphic stage (b)

the MD of younger stages of $A$. anguilla larvae is less than the before-mentioned values, but there are no comparable data in the literature. Leptocephali of $A$. rostrata possess only 61-66 predorsal myomeres (Smith, 1989).

Number of preanal myomeres (MA) and preanal length (preAL)

The number of preanal myomeres was counted in 370 leptocephali; the values found ranged between 67 and $75(\varnothing=71.21$; s.d. $=1.58$; cf. Table 1, Fig. 4). A comparison with Schoth (1982) surprisingly shows a difference in the means of almost 5 myomeres. Ford (1931) assumed the position of the anus to be constant during the whole larval life. According to Schoth, the difference in the frequency distribution of MA of the young development stages of $A$. anguilla and $A$. rostrata is highly significant $(\varnothing=64.88$ for A. rostrata, $\varnothing=66.56$ for $A$. anguilla). Under no circumstances may this characteristic be 
used for a distinction of Anguilla larvae of all development stages, because the MA of larger $A$. rostrata larvae is very similar to that of $A$. anguilla (Smith, 1989: 68-73 MA).

The higher values of the MA of older and larger $A$. anguilla larvae present an apparent contradiction to the phenomenon of the relative decrease in preanal length during the larval phase (Fig. 5). Two separate developmental processes seem to be taking place here: on the one hand a caudally directed shifting of the anus in relation to the muscle segments and, on the other hand, a decrease in the relative preanal length.
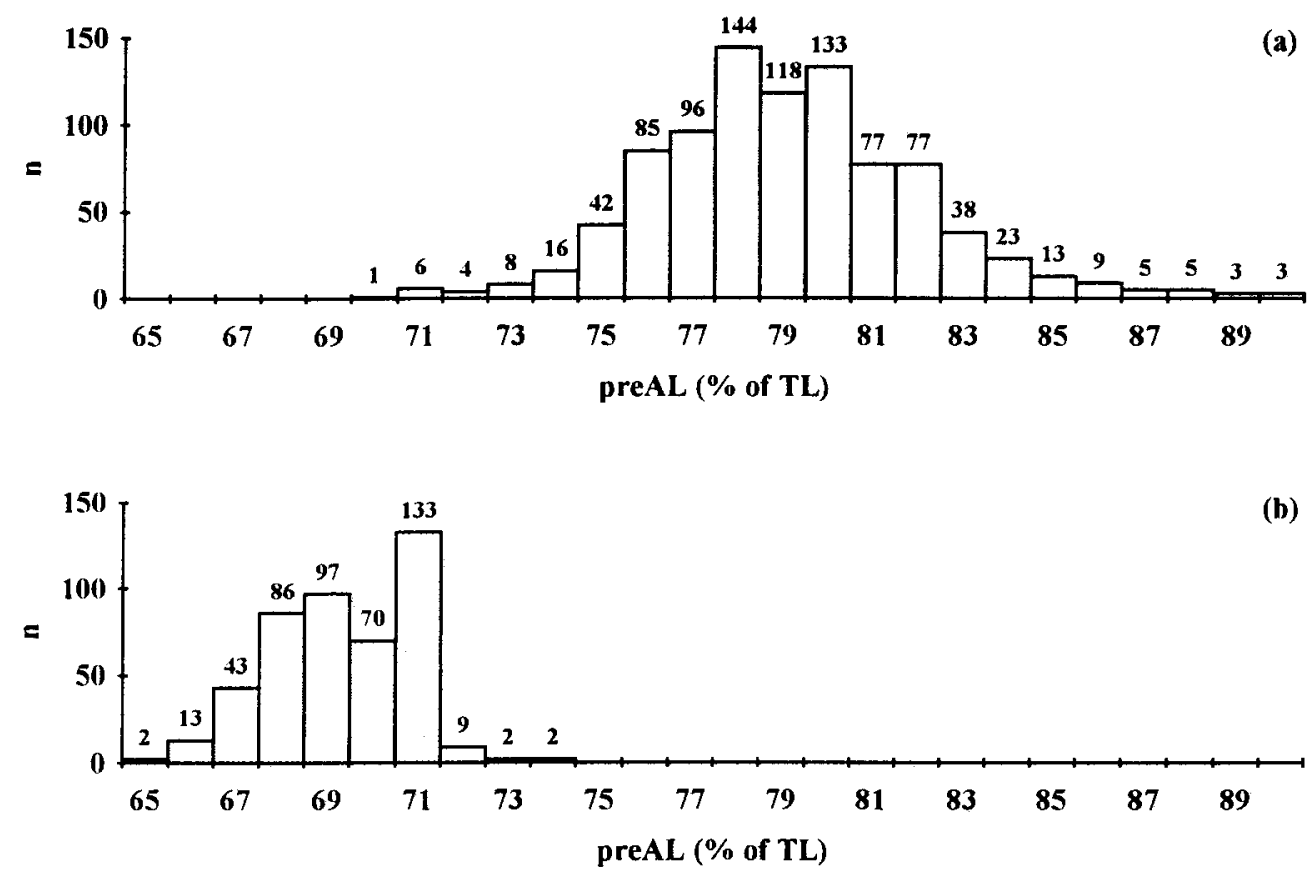

Fig. 5. Frequency distribution of the relative preanal length (preAL) for leptocephali of Anguilla anguilla of O-group (a) and premetamorphic stage (b)

The relative preanal length is described as the distance between the tip of the snout and the anus, and depends on the total length of the treated specimen. The decrease in the preAL can be explained by measuring the body proportions which change during the larval phase (Berndt, 1938; Schoth, 1982; Strehlow, 1988). In young stages, the head which is included in the preAL presents an essentially greater share of the total length (up to $15 \%$ of TL - pers. comm. Rohlf) than in older A. anguilla larvae.

Schoth described a slightly decreasing length of the intestine with increasing TL in both Anguilla species even within the 0-group stage ( $\mathrm{TL}=5 \mathrm{~mm}: 76.3 \%$ of $\mathrm{TL}$; $\mathrm{TL}=$ $29 \mathrm{~mm}: 75.2 \%$ of TL for $A$. anguilla). The results varied between 70 and $90 \%$ of TL. Within the II-group of $A$. anguilla larvae a similar tendency was not evident. The difference between the preAL of 0 - and II-group is highly significant, but only the initial and the final phase of larval life have been investigated whereas values for intermediate stages are still lacking. It is therefore not known if the decreasing process is a straight one. 


\section{Other characteristics}

The mean relative length of head (LH) amounted to $5.65 \%$ of the TL, the results in 368 examined larvae varying between 4.7 and $6.5 \%$ of the TL (s.d. $=0.44$ ). Therefore, the head represents only a very small part of the larval body. The average relative diameter of eyes of 376 leptocephali was $28.7 \%$ of the LH $(23.1-33.4 \%$ of the LH). The mouth cleft takes up, on average, $53.5 \%$ of the $\mathrm{LH}$, the results of 378 analysed specimens lying between 44.2 and $65.5 \%$ of the LH.

\section{Geographical and genetical considerations}

The leptocephali of $A$. anguilla and $A$. rostrata are essentially identical; they are distinguished by the number of myomeres only. The geographical position can therefore assist the meristic identification; the larvae of $A$. anguilla are more common in the eastern Atlantic. Schmidt (1922) found that west of about $62^{\circ} \mathrm{W}$ and south of about $24^{\circ} \mathrm{N}$ leptocephali are mainly of $A$. rostrata, but north and east of these limits $A$. anguilla larvae prevailed. The investigation of meristic and morphometric characters that forms the basis of the hypothesis of two genetically separate Anguilla species in the Atlantic Ocean was supported by the demonstration of significant differences in malate dehydrogenase enzymes (Williams \& Koehn, 1984) and mitochondrial DNA (Avise et al., 1986). But there are also evolutionary hypotheses that, basing on the presence of hybrids in the Icelandic eel population, account for the original separation of North Atlantic eels into European and American populations (Williams et al., 1984; Avise et al., 1990).

The hitherto easternmost record of an $A$. rostrata larva was a specimen of $70 \mathrm{~mm}$ total length from $49^{\circ} 43^{\prime} \mathrm{N}, 20^{\circ} 45^{\prime} \mathrm{W}$ (Kleckner \& McCleave, 1985). One larva of $68.7 \mathrm{~mm}$ total length from the 1984 collection $\left(37^{\circ} 53^{\prime} \mathrm{N}, 14^{\circ} 0.5^{\prime} \mathrm{W}\right)$ possessed only 107 myomeres, and 44 myomeres up to the opistonephritic blood vessel. It is the hitherto southernmost record of an A. rostrata larva in the eastern part of the Atlantic and it was identified by a features combination.

Acknowledgements. I would like to thank E. Biester, F.-W. Tesch and H.-D. Bast for critical discussion, and C. Berger for valuable hints concerning the English text.

\section{LITERATURE CITED}

Avise, J. C., Helfman, G. S., Saunders, N. C. \& Hales, L. S., 1986. Mitochondrial DNA differentiation in North Atlantic eels: Population genetic consequences of an unusual life history pattern - Proc. ntn. Acad. Sci. U.S.A. 83, 4350-4354.

Avise, J. C., Nelson, W. S., Arnold, J., Koehn, R. K., Williams, G. C. \& Thorsteinsson, V., 1990. The evolutionary genetic status of Icelandic eels. - Evolution 44, 1254-1262.

Bast, H.-D. \& Klinkhardt, M., 1987. Distribution of some mesopelagic fishes in the Iberian Basin (eastern central North Atlantic), Part I. - Wiss. Z. Univ, Rostock (R. Math. Naturwiss.) 36, 57-64.

Bast, H.-D. \& Strehlow, B., 1990. Length composition and abundance of eel larvae, Anguilla anguilla (Anguilliformes: Anguillidae), in the Iberian Basin (northeastern Atlantic) during July-September 1984. - Helgoländer Meeresunters. 44, 353-361.

Berndt, O., 1938. Morphologie und Histologie des Rumpfdarmes von Anguilla fluviatilis und die Veränderungen desselben im Individualzyklus. - Zool. Jb. (Anat. Ontogenie Tiere) 64, 437-482.

Blache, J., 1977. Leptocephales des poissons anguilliformes dans la zone sud du Golfe de Guinée.Faune trop. 20, 1-381. 
Böetius, I., 1980. Atlantic Anguilla - a presentation of old and new data of total numbers of vertebrae with a special reference to the occurrence of Anguilla rostrata in Europe.- Dana 1, 93-112.

Castle, P. H. J., 1984. Elopiformes, Notacanthiformes and Anguilliformes. In: Ontogeny and systematics of fishes based on an International Symposium dedicated to the memory of Elbert $H$. Ahlstrom. Ed. by H. G. Moser \& W. J. Richards. Allan, Lawrence, Ks, 94-102 (Spec. Publ. Am. Soc. Ichthyol. Herpet. 1.).

Ege, W., 1939. A revision of the genus Anguilla (Shaw); a systematic, phylogenetic and geographical study. - Dana Rep. 16, 1-256.

Ford, E., 1931. Changes in the length during the larval life and metamorphosis of the freshwater eel (Anguilla vulgaris Turt.), - J. mar. biol. Assoc. U. K. 17, 987-1000.

Jespersen, P., 1942. Indo-Pacific leptocephalids of the genus Anguilla. - Dana Rep. 22, 1-128.

Karmovskaya, E. S., 1990. Leptocephali of the eels of the genus Nemichthys (Nemichthyidae, Anguilliformes). - Vopr. Ikhtiol. 30, 551-563.

Kleckner, R. C. \& McCleave, J. D., 1980. Spatial and temporal distribution of Anguilla rostrata and Anguilla anguilla leptocephali found in North American ichthyoplankton collections. - C. M./ ICES, $M 21,1-18$.

Kleckner, R. C. \& McCleave, J. D., 1985. Spatial and temporal distribution of American eel larvae in relation to North Atlantic Ocean current systems. - Dana 4, 99-128.

Kracht, R., 1982. On the geographic distribution and migration of I- and II-group eel larvae as studied during the 1979 Sargasso Sea Expedition. - Helgoländer Meeresunters. 35, 321-327.

Schmidt, J., 1909. Remarks on the metamorphosis and distribution of the larvae of the eel (Anguilla vulgaris, Turt.). - Meddr Kommn Havunders.(Ser. Fisk.) 3 (3), 1-17.

Schmidt, J., 1913. First report on eel investigations 1913, - Rapp. P.-v. Réun. 18 (2), 1-29.

Schmidt, J., 1922. The breeding places of the eel. - Phil. Trans. R. Soc. (B) 211, 179-208.

Schoth, M., 1982. Taxonomic studies on the 0-group eel larvae (Anguilla spec.), caught in the Sargasso Sea in 1979. - Helgoländer Meeresunters. 35, 279-287.

Smith, D. J., 1979. Guide to the leptocephali (Elopiformes, Anguilliformes and Notacanthiformes). NOAA tech, Rep.( NMFS Circ.) 424, 1-39.

Smith, D. J., 1989. Family Anguillidae: Leptocephali. In: Fishes of the western North Atlantic. Ed. by E. B. Böhlke. Sears Foundn Mar. Res., Yale Univ., New Haven, 9,2, 898-899.

Strehlow, B., 1988. Fischereibiologische Untersuchungen an Leptocephali aus dem Nordatlantik zwischen den Azoren und der Iberischen Halbinsel. Dipl.Arb., Univ. Rostock, 104 pp.

Strehlow, B., 1990. Untersuchungen an Leptocephali und adulten Exemplaren der Ordnung Anguilliformes aus dem Iberischen Becken und dem Seegebiet vor Nordwest-Afrika. Diss., Univ. Rostock, $210 \mathrm{pp}$.

Vladykov, V. D. \& March, H., 1974. Distribution of leptocephali of the two species of Anguilla in the western North Atlantic, based on the collections made between 1933-1968. - Syllogeus 6, 1-38.

Williams, G. C. \& Koehn, R. K., 1984. Population genetics of North Atlantic catadromous eels (Anguilla). In: Evolutionary genetics of fishes. Ed. by B. J. Turner. Plenum Press, New York, $529-560$.

Williams, G. C., Koehn, R. K. \& Thorsteinsson, V., 1984. Icelandic eels: Evidence for a single species of Anguilla in the North Atlantic. - Copeia 1984, 221-223.

Wippelhauser, G. S., McCleave, J. D. \& Kleckner, R. C., 1985. Anguilla rostrata leptocephali in the Sargasso Sea during February and March 1981. - Dana 4, 93-98. 